\title{
Figuring Africa and China
}

\section{Congolese Literary Imaginaries of the PRC}

\author{
Duncan M. Yoon \\ New York University, New York, NY, USA \\ dmyoon@nyu.edu
}

\begin{abstract}
This article asks how China has figured as a trope in Congolese literature from the Cold War and to the present. To do so, I analyze three texts: V.Y. Mudimbe's Entre les eaux (Between Tides) (1973), In Koli Jean Bofane's Congo Inc. (2014), and Fiston Mwanza Mujila's Tram 83 (2014). I also examine how Mobutu interpolated Maoism into his dictatorship. I argue that whereas the Cold War produces figures such as the Maoist guerrilla, the radical intellectual, and the authoritarian leader, Chinese investment in the DRC facilitates the rise of new figures such as the mondialiste and the economic tourist. As a result, Third Worldism is ironically recast through the lens of a mutual "win-win" for development. This lens masks a new era of extractivism that produces its own social dislocations, which lends Pierre Mulélé's Maoist-inspired rebellion a paradoxical relevance to DRC-PRC relations at the beginning of the twenty-first century.
\end{abstract}

\section{Keywords}

Africa - China - Congo - Mulélé - Maoism 
The exponential increase in the People's Republic of China's investment in Africa is now well documented. ${ }^{1}$ Since 2005 , China ${ }^{2}$ has invested over 373 billion dollars in Africa (Northern and sub-Saharan), which represents just 19 percent of their overall global investment. Although nowhere near as precipitous, African investment is estimated at $\mathbf{1 4 . 2}$ billion dollars in 2012, which is a 43 percent change from 9.9 billion dollars in $2008 .{ }^{3}$ Trade is also at an all-time high between the continent (fifty-four countries) and the PRC, reaching a little over 204 billion dollars in 2018 alone. Due to their natural resource richness and market potential, the Democratic Republic of the Congo (DRC) is one of the PRC's main partners, with over 14.66 billion dollars invested from 2005 to $2019 .{ }^{4}$

Although most research on DRC-PRC relations, and Africa-China relations in general, focuses on the contemporary developments, the two countries have had a long history of exchange, reaching back to Congolese independence in 1960 and the ensuing Congo Crisis. The transnational history even stretches into European colonialism, wherein Chinese coolie labor was brought to neighboring Brazzaville to help construct the Congo-Océan railway from $1922-1934 .^{5}$ As Jamie Monson has noted, it is imperative to historicize twenty-first-century interactions to avoid a presentism that is easily and often sensationalized by media headlines. ${ }^{6}$ In this spirit, and due to the relative paucity of humanities scholarship on DRC-PRC relations, this article asks how China has figured as a trope in Congolese literature from the Cold War and to the present. ${ }^{7}$

To do so, I analyze three novels:V.Y. Mudimbe's Entre les eaux (Between Tides) published in 1973, In Koli Jean Bofane's Congo Inc. (2014), and Fiston Mwanza Mujila's Tram 83 (2014). I also briefly analyze how the Congo-Brazzavillian

1 The following is an extremely cursory list of political economy texts: Ian Taylor's China and Africa (2007) and China's New Role in Africa (2009); Chris Alden's China in Africa (2010); Chris Alden, Daniel Large, and Ricardo Soares de Oliveira's China Returns to Africa (2008); Deborah Brautigam's The Dragon's Gift (2009) and Will Africa Feed China? (2015); and Joshua Eisenmann and David Shinn's China and Africa (2012).

2 While I use "China" as a shorthand for "the People's Republic of China" in this article, in no way do I mean to occlude the many kinds of sinophone communities that exist. See Shih 2007.

3 See "China Global Investment Tracker" (2015).

4 See "Data: China-Africa Trade." China Africa Research Initiative.

5 See van Waijenburg 2018.

6 See Monson 2020.

7 This trend is changing. See Banham, Gibbs, and Osofisan 2016; Batchelor and Zhang 2017; Thornber 2016; and Vasser 2019. 
author Emmanuel Dongala represents the Mulélé Rebellion in Un fusil dans la main, un poème dans la poche ( $A$ Gun in the Hand, A Poem in the Pocket) (1973). ${ }^{8}$ In addition, I examine how Mobutu Sese Seko interpolated Maoism into his dictatorship, which provides an authoritarian segue from Third World radicalism to contemporary extractivism, a term I use to distinguish between Western (neo)colonialism and PRC investment. ${ }^{9}$ The article places particular emphasis on Entre les eaux because of the lack of scholarship on this groundbreaking text as well as the importance of using Cold War imaginaries, hitherto underexamined in scholarship on Africa and China, to understand the current context.

I argue that whereas the Cold War produces figures such as the Maoist guerrilla, the radical intellectual, and the authoritarian leader, Chinese capital investment in the DRC facilitates the rise of a new figures such as the mondialiste and the economic tourist. As a result, the Third Worldism of the Cold War is recast through the official diplomatic lens of a mutual "win-win" for development. This lens masks a new era of extractivism that produces its own social dislocations, which lends Pierre Mulélé's Maoist-inspired rebellion a paradoxical relevance to DRC-PRC relations at the beginning of the twenty-first century. In sum, these texts map the longue durée of DRC-PRC relations, figuring and reconfiguring the dynamic through the potent postcolonial critique embedded in their literary imaginaries.

Présence Africaine published Entre les eaux in 1973, which won Le grand prix catholique de Littérature in 1976. The novel depicts a Catholic priest from the Congo, Pierre Landu, who leaves his parish to become a guerilla fighter, or maquisard, convinced that "it is Karl Marx who has best personified concerned evangelical love over the last century" (Mudimbe Between 93). In a 1980 interview, Mudimbe relates that Landu is "an image, no doubt exaggerated [...] of who African intellectuals are” (Gasana 222). This image of the intellectual, I

8 All three of these authors reside outside of the DRC. The question of Congolese literature and its diaspora is important to authorial positionality and citizenship, but lies outside the scope of this essay.

9 I follow Russell West-Pavlov here in focusing on extraction. West-Pavlov writes of necropolitics in the Congo: "Territory, the built environment, the land, the soil, and finally the human population are all subject to the predatory logic of the so-called 'extractive industries'” (112). 
might add, is geopolitically linked to the Cold War. The narrative was inspired by the real events of the two priests, Placide Tara and Adolphe Lankwam, who served as part of Mulélé's inner circle in Kikwit. ${ }^{10}$ Through Landu's tortured interior monologue, the narrative depicts the Maoist-inspired atmosphere of the maquis - the strict code of conduct, educational sessions, military training, and missions - even as Mulélé is never mentioned by name.

The leader of the maquis, who is known only as the Colonel, and the priestturned-revolutionary, Landu, quickly connect on an intellectual level. They debate theology, revolution, and pan-Africanism, as well as the nature of faith and conviction. One particularly arresting passage captures the nuances of their exchange and deserves to be quoted at length:

And my own people were challenging that world in the name of a negritude that discouraged me utterly with its pretensions to eternal existence. Must I place my Faith in that mystification as well? This multiplication of acts of Faith was frightening.

'Colonel: suppose the Europeans began to talk about 'blanchitude."

'They'd make millions happy overnight. Look at the Nazis. And you know Denis de Rougemont's thesis ...'

'But from the Marxist point of view? The Second International Congress handed down perfectly clear decisions about national and colonial questions.'

'But you yourself talk about Castro. Do you know the Cuban road to communism?'

'Gee! What's the final authority in this camp?' He was plucking me apart. My anger was a form of cowardice, a desperate stand against sophisticated complexity. Always nuances, connections, compromises, polite excuses. Finally a talent for lying. I met his gaze briefly; nervously I stared at his left ear, waiting for my defeat.

'As you must know ...' He paused. I felt his burning gaze, and glanced up to see a voracious beast. I worried: Just what was he defending? He went on.

10 In that same interview, Mudimbe elaborates: "Effectivement, dans les années des rébellions au Zaïre, il y a eu un prêtre qui a vécu avec des maquisards. Je ne sais pas s'il a pris les armes. En tout cas, il a vécu avec des maquisards et il avait fait le choix de vivre avec eux" ["In effect, in the years of the rebellions in Zaire, there was a priest who lived with the maquis. I don't know if he took up arms. In any event, he lived with the maquis and he had made the choice to live with them"] (224). I thank Matt Reeck for this translation. 
'As you must know, the final authorities are Marx, Lenin, and Mao Mao above all. Socialism subsidized does not imply servitude. It is not like the Church. Care to comment on that, my little priest?'.

MUDIMBE Between $86-87$

As scholars have documented, Entre les eaux articulates how the postcolonial Congolese intellectual, who is intent on finding the right path to decolonization, is caught between dueling dogmas and their requisite teleologies - colonialism and Christianity, négritude and nativism, and finally, Marxism and revolution. ${ }^{11}$ For Landu, each of these paths, whether secular or not, represents an act of faith, or an act of mystification. The passage suggests that mystification is akin to belief - to take one instance, one example, and amplify it to a universal category, into "eternal existence." This amplification creates a hierarchy, an order of things based on assimilation or annihilation. ${ }^{2}$ Landu struggles to reconcile his understanding of Christ - a revolutionary figure fighting for social justice at the edge of the Roman Empire - with how Christianity has become the legitimizing myth of colonial capitalism and its accompanying racist hierarchies.

To deal with these racist hierarchies, thinkers like Aimé Césaire and Léopold Sédar Senghor turned to a pan-Africanism as négritude. In its reduced form, négritude has been criticized for perpetuating its own form of racial essentialism. Landu struggles with this form of racial essentialism that serves as the primary source of anticolonial struggle, precisely for how he believes it mystifies - that is, essentializes - Blackness. Although this reading of négritude as a racial essentialism has been complicated by scholars such as Souleymane Bachir Diagne, the passage pinpoints how this form of pan-Africanism was misread as an unqualified response, however necessary, to the racist discourses of World War II. ${ }^{13}$ The Colonel even extends the debate to the Swiss thinker Denis de Rougemont, and how he promoted a common pan-European identity, a "blanchitude," during the postwar period, which paved the way for the federalism of the European Union. ${ }^{14}$

In his continued search for a truth, a "final authority" to believe in, Landu moves from négritude's mystification to Marxism, and specifically to how the Soviet Comintern condemned colonialism during the Second International

11 See Diawara 199o; Kisukidi 2013; Kasende 20o1; Slaymaker 1996; Linares 1996; and Kapanga 2006.

12 See Glissant 1997.

13 See Diagne 2011 and 2019.

14 See Swedberg 2016. 
Congress of 1920. The Colonel obliges, but moves beyond the Comintern as his sole revolutionary inspiration, despite how the Soviets sought to aid "the revolutionary movement in the colonies both materially and morally" (Congress 117). At this point, the Colonel is aware Landu is seeking a dogmatic certitude on which to base his revolutionary faith, and gestures to the importance of Cuban communism to the Congolese cause, historically exemplified by how Che Guevara himself joined up with the Eastern front of Mulélé's movement, the Simba Rebellion in the Kivu. ${ }^{15}$ The Colonel's turn to Third World Marxism frustrates Landu, who sees in the leader's game a flouting of orthodoxy's clarity. An irony thereby emerges in how the apparent certitude of Marxism as a grand narrative is belied by its myriad variations, gesturing to an anger-inducing anxiety over the inability to ascertain the correct genealogy, the correct cause and effect that brings about the revolution's success.

Landu desires desperately to believe in the right dogma, which, the passage suggests, is full of its own contradictions, "nuances, connections, compromises" and "polite excuses" (Mudimbe Between 83). These contradictions ultimately necessitate a "talent for lying" in order to reconcile oneself to action (83). Exasperated, Landu then exclaims, "Gee! What's the final authority in this camp?" (83). In response, the Colonel cuts their theoretical debate short and Pierre feels his "burning gaze [...] I was worried: Just what was he defending? He went on. 'As you must know, the final authorities are Marx, Lenin, and Mao - Mao above all'" (83). Landu quickly realizes that in the end there is no dogmatic ambiguity for the Colonel, and that the debate was an attempt to draw the priest's allegiances out in an ideological test. The Colonel's revolution is allconsuming, a "voracious beast" that will brook no hesitation; he believes the correct Marxist genealogy for the Congolese revolutionary, for decolonization from (neo)colonialism, ends in Mao Zedong and the Chinese Revolution. The maquis' Marxism takes its cues from the PRC and thus the Colonel cannot permit a "hundred flowers to bloom."16

The way in which the Colonel cites Mao Zedong as the final authority for Congolese Marxism points to how pervasive the Chinese Revolution had become as an anticolonial symbol by the 196os. Because of Maoism's controversial legacy as yet another example of authoritarianism, scholars of African postcolonialism have hesitated to place Maoism into the intellectual geneal-

\footnotetext{
15 See Gott 1996.

16 See Mao, et al. 1989.
} 
ogy of African decolonization, and justifiably so. Mudimbe's Entre les eaux, however, captures this atmosphere of Third Worldism, as well as the figure of the African Mao as both guerrilla fighter and radical intellectual - the physical embodiment of Afro-Asian solidarity. Yet the Colonel rejects Landu's implication that the rebels might be controlled by Beijing: "Socialism subsidized does not imply servitude. It is not like the church" (Mudimbe Between 83). Although not explicitly stated in the novel, the Colonel's ideological zealotry and how it extends to the rest of the rebel camp (including in the fact of the priest Landu's own first name, Pierre) is intended to conjure up Pierre Mulélés singular force of personality.

Many accounts of Mulélé describe his quasi-divine status among the rebels and his perceived invulnerability, a persona that spread across the two main fronts of the rebellion: the Mulélé-led Kwilu resistance in the West that began in the summer of 1963; and the more famous Simba Rebellion in the Eastern Kivu province, a rebellion that had not only seen Che Guevara join the ranks of its revolutionaries in April 1965, but whose fighters had also occupied Stanleyville (Kisangani) in August 1964, with Gaston Soumialot declaring the short-lived independence of the People's Republic of the Congo (PRC) that September. ${ }^{17}$ Both movements combined in the figure of Mulélé the power of the supernatural with radical politics.

In his Rebellions au Congo (1966), Benoît Verhaegen writes how the "principal bearer of magical power was not a sorcerer but Mulélé himself" (126)..$^{18}$ Through demonstrations including being shot with blanks to prove his invulnerability, he "made it appear to his partisans that he had a superior power to that of all of his enemies" (126). Stories spread that he could metamorphize into a serpent in order to check up on different parts of the movement, causing followers to exclaim "'Hello, Comrade!" when they "me[t] a snake in the forest" (126). He could "turn invisible" or "fly for long distances like a bird or a spirit" and even "stop flying bullets with his hands" due to "'nkisi' (sorcerer's potions)" (126). Mulélé extended his invincibility to other guerrilla fighters through both a "ritual of magical immunization," and strict adherence to a code of conduct (127). Once in battle, "the combatants had to coat themselves with dirt and advance while shouting 'Mai, mai'! [water]. Mulélé had told them that the enemy bullets would change into harmless mud puddles" (125). If a guerrilla did fall, it was

\footnotetext{
17 Not to be confused with the later Brazzaville-based Marxist-Leninist state led by Marien Ngouabi and founded in 1969 .

18 I thank Matthew Reeck for his translations of the Verhaegen text.
} 
only "the proof of misdeeds he had committed. Dead partisans weren't thought of, weren't the cause of any grief, because they had broken the code" (125).

\subsection{Mao as Fetish Object (an Aside)}

I will soon examine how this draconian code of behavior manifests in Entre les eaux, and in particular as a derivation from guerrilla tactics discussed in The Military Writings of Mao Zedong (1964). But first, I would like to briefly turn to a passage in Emmanuel Dongala's Un fusil dans la main, un poème dans la poche (1973), which captures the inextricability of the two Congos' revolutionary histories, as well as the symbolic function of Mao in both contexts. The novel's protagonist, Mayéla dia Mayéla, is a pan-Africanist freedom fighter who eventually becomes the leader of the fictional Republic of Anzika. His name suggests both one of Mulélé's deputies, "Mayele," as well as Amílcar Cabral's anticolonialism, through the use of the Portuguese word dia, or "day" (Verhaegen Rebellions 115).

In this passage, Mayéla pauses in front of a monument dedicated to Patrice Lumumba in Kisangani (Stanleyville) on his way back to Anzika through the DRC. This moment of reflection

left him with a feeling of malaise, as though he lived in a world one step away from reality; he saw again Muléle troops overwhelming the enemies outfitted with tanks and machine guns, with nothing more for weapons than Mao's red book in one hand, fetishes around their necks, a spear or a bow and arrows in the other hand. ${ }^{19}$

DONGALA 224

His own maquis defeated and in disarray, Mayéla signals his disillusionment with the revolutionary scheme, gesturing to how the world of the guerrilla lies outside reality, a world wherein the matrix of time and space grows according to the inevitability, however continually deferred, of the people's triumph; it is a spatio-temporality of a dogmatic iconoclasm, an urgency endured. In this passage of interior monologue, the scene flashes back to the paradoxical image of the Muléléliste throwing him or herself into battle against the much better equipped Congolese National Armed Forces (ANC), full of Belgian mercenar-

19 "lui laissait une impression de malaise, comme s'il vivait dans un monde au bord de la réalité; il revit les troupes de Mulélé fonçant sur des ennemis armés de chars et de mitrailleuses, avec pour seules armes un livre rouge de Mao à la main, des fétiches autour du cou, une lance ou un arc et des flèches dans l'autre main." I thank Matthew Reeck for his translation of Dongala's text. 
ies bent on colonial revenge for "the humiliations inflicted upon the White Man from Indochina to Algeria, from the Kenya of Mau Mau to the Congo of Lumumba"20 (224).

The Mulélélistes make up for their technological disadvantage with blind faith in the revolution's power. This invincibility is sanctified by protective amulets "made of human fingernails" as well as "magical immunization" by the "fetish-doctor who would make a brief incision into which he would apply either a liquid or a powder of a dark color" (Verhaegen Rebellions 127). They combine the supernatural with the dogmatism of Mao's Little Red Book, now transformed from tactical manual into sacred text. The Little Red Book has thus become a fetish object par excellence, imbued with the protective power of Afro-Asian solidarity in the face of neocolonialism.

These objects connect the real world to the people's revolution as spiritual warfare, transforming mental and physical states through Maoist scripture and traditional psychedelics. Channeling this altered consciousness in front of the monument dedicated to Lumumba, Mayéla continues to hallucinate, hearing "the shouts of 'Maé Mulélé' rising, escaping the crack of gunfire and the roaring of cannons"21 (Dongala 224). Now fully entered into the supernatural spatiotemporality of the revolution, the guerrillas have smeared themselves with the soil of the Congolese homeland (Kwilu or Kivu), calling upon Mulélé to transform Belgian bullets into "mae," or water, as they advance against "the army with modern arms"22 (224).

\section{2 "The Debauchery of Empty Symbols" (Continued)}

In Entre les eaux, this spirit of Afro-Asian solidarity resides in both the Third Worldism of the Colonel and, through Landu, in the contradictions between Catholicism and colonialism. Landu believes "the source of my affliction" lies in how he has been told a "truly profound Christianity [...] is in permanent contact with the values of Christian civilization," an "axiom" that "produced black priests and bishops, just as it justified bashing the $\mathrm{N}[\ldots]$ every now and then somewhere in the world. Or the Yellow Peril. Pretty much the same" (Mudimbe Between 78). The passage suggests that Congolese solidarity with

\footnotetext{
20 "des humiliations infligées à l' homme blanc de l'Indochine à Algérie, du Kenya des Mau Mau au Congo de Lumumba."

21 "les cris de 'Maé Mulélé' montaient, envahissaient le crépitement et le grondement des canons"; "Maé" is in fact a particular rendering of "maji" in Swahili. It is also rendered "mayi" and "mai" in Lingala and Kikongo, respectively. I thank my peer reviewer for this observation.

"l' armée aux armes modernes."
} 
the PRC resides in a collective anti-racism that effects decolonization by reinterpreting Marxism through historical, cultural, and racial difference. Such a critique captures the hypocrisy of how colonialism systematically dehumanized the African or Asian Other in order to proclaim the alleged humanity at the heart of Christian civilization. ${ }^{23}$ The Colonel thereby believes Maoism symbolizes a postcolonial Marxism, invoking how from April 1962 to July 1963 Mulélé and Théophile Bengila were in the PRC studying Maoist political theory and receiving training in guerrilla tactics. ${ }^{24}$

The novel captures this Cold War anxiety over Chinese indoctrination of the Mulélélistes as Landu, in a moment of frustration with the "demagogue" teaching classes in the maquis, thinks, "In Charlesville the newspapers report that Chinese ideologues are training and arming us. I haven't seen one yet" (15-16). The passage underscores how although the PRC was quite vocal in its rhetorical support of the Mulélélistes, support in the form of troops and munitions was in fact quite limited during this period. ${ }^{25} \mathrm{~A}$ variety of factors could have contributed to this lack of material support, ranging from the domestic turmoil caused by onset of the Cultural Revolution in China, to how the actual assistance the PRC could muster was focused on completing the anti-apartheid railway in neighboring Tanzania and Zambia. ${ }^{26}$ However, the novel demonstrates how the media in the capital (Charlesville as a possible reference to either Stanleyville or Leopoldville) amplifies the discourse of yellow peril, a trope that often resurfaces in contemporary literature on Africa-China relations.

Adherence to a rigid code of behavior, tactical training in guerrilla warfare, and classes in Marxist theory made up a large part of the maquis' culture. In Entre les eaux, Landu takes up all of these activities, communicating their effect to the reader through an increasingly tortured interior monologue. In one pas-

23 See Césaire and Kelley 2000.

24 Refused by Moscow, Ludo Martens writes, "Mulélé came to Beirut. He confessed his confusion to the Chinese ambassador. Several weeks later, he was admiring the immense square of Tien An Men in Peking. From April 1962, Mulélé and Bengila received political and military training and assimilated the lessons of the Chinese Revolution. Mulélé dedicated himself in particular to learning the necessary techniques for guerilla warfare. He learned how to make mines and explosives following artisanal techniques, to repair and make guns, transmitters, and radios, he studied military topography. Bengila took up questions of strategy and guerilla tactics" (Pierre 133). I thank Matthew Reeck for his translation of the Martens text.

25 "China continued to support African liberation movements throughout the Cultural Revolution, but its preoccupation with internal developments diminished its ability and willingness to engage as actively as before" (Shinn and Eisenman 39).

26 See Monson 2009. 
sage, Landu describes education sessions with an instructor who has a "thin, chanting eunuch's voice. Theoretically his job is to lecture us on the sociology of colonial societies. He joined up to make war on the revisionists, the unreliable elements. Traitors, with their misreadings of Marx. He gives me the willies" (15). While this earlier session features Lenin's Imperialism, the Last Stage of Capitalism (1917), in a later session with one of the cell leaders, Bidoule, they read from another text "translated into African languages by the Colonel [...] André-Paul Lentin's last book on the tricontinental struggle," La lutte tricontinentale (1966) (Mudimbe Between 104). Bidoule lists a series of statistics on "the imperialist government of the United States," which "can raise an army of 3,000,0oo men [...] 2,6oo nuclear warheads [and] 3,50o fighter-bombers with nuclear capability, with an explosive power of 25,00o megatons" (104). Yet Bidoule's take-away for the maquis is that "they are paper tigers, as Mao stated. Look at Vietnam ..." (104).

Landu trades the didacticism of the seminary for that of the maquis, and yet, just as he struggled with reconciling himself to the contradictions of Catholicism and colonialism, he is uncomfortable with the singular zeal embodied by the instructor. The instructor has joined the maquis to purify the revolution, to purge this Congolese Marxism of its reactionary elements. Geopolitically speaking, Mulélés Rebellion takes place against the Cold War backdrop of the Sino-Soviet split, which had finally come to a head in $1963 .{ }^{27}$ By returning to Lenin's seminal text through the lens of ridding reactionary interpretations, the instructor seeks to distill the "permanent revolution" from what he deems as later Soviet perversions of dogma: he rereads Lenin from a Maoist perspective in order to rehabilitate a Marxism that has not lost its so-called connection to the masses of people.

The second session on Lentin's La lutte tricontinentale again captures the global geopolitical shifts of the 196os. The passage first gestures to a politics of language that insists on translating revolutionary texts into local languages. It then captures the way in which America's defeat in Vietnam galvanized Third Worldism, crystallized by how Bidoule cites Mao's famous declaration in 1946 to the journalist Anna Louise Strong that America was only a "paper tiger."28 The Vietnam War signaled a symbolic shift for many formerly colonized countries because it revealed the extent to which they felt the United States had emerged post-World War II as the global hegemon. Furthermore, by shifting from European colonialism to what many deemed as American neocolonial-

27 See Lüthi 2010.

28 See Strong and Keyssar 1985 . 
ism, the global revolution became properly tricontinental. With the first Tricontinental Conference in Havana in 1966, the anticolonial Afro-Asianism of Bandung and the anti-Americanism of Latin American countries came to a head. ${ }^{29}$ Ho Chi Minh's use of guerrilla warfare as well as Che Guevara's shift of revolutionary focus to central Africa coalesced with the ideological "purification" of Marxism embodied by the Sino-Soviet split. This turn to Maoism as the doctrinally correct, Third World interpretation of Marxism meant that the Congo had become the next concentrated site of global revolution.

Despite not being explicitly featured in Entre les eaux, Mao's Little Red Book was also used as a primary document for education in the camps, often referred to Lingala and Kikongo as "malongi ya politique" (quoted in Kikumbi 161). Interviewed as recently as 2015, a partisan describes a similar scene of indoctrination wherein "the monitors were always carrying around a little book by Mao that they were constantly quoting from while inside the tents of the maquis. They kept insisting on the need to fight against social inequalities" (quoted in Kikumbi 153) $\cdot{ }^{30}$ Even the status of women within the Chinese Revolution was held up as exemplary. Abo Léonie (partisan and wife of Mulélé) describes a conversation partisans had with Mulélé, "You see what women can do in socialist countries. In China, I saw women working as engineers, as CEO s, I even saw some leading soldiers, driving tanks" (Martens Une femme 84). The strict code of behavior that insisted on relative abstinence in Mulélé's camps was in part a response to his experience of living in the PRC for a year where he allegedly "didn't know a single Chinese woman [...] when you're at war, you can't think too much about that. There are other things to do. In this case, too, it's their president Mao who educated them about this" (84).

In his memoir of the maquis, Théophile Bula-Bula also speaks of this Maoistinspired code of behavior, which he describes as "the difference between the revolutionary soldier and the reactionary soldier, the soldier of the people had to live with the masses. It's the principle of the fish in the ocean, a principle dear to Mulélé" (45). ${ }^{31}$ Bula-Bula references a famous Maoist saying, often attributed to On Guerrilla Warfare (1937): "the people are the sea that the revolutionary swims in," or in another version, "the guerrilla must move among the people as a fish swims in the sea." ${ }^{32}$ Mulélé was directly inspired by Maoism, and

29 See Mahler 2018. See also Young's section on the Tricontinental in Postcolonialism: An Historical Introduction (2016).

$30 \quad$ I thank Matthew Reeck for his translations of the Kikumbi text.

31 I thank Matthew Reeck for his translations of the Bula-Bula text.

32 The full quote from the 1937 text is: "Many people think it is impossible for guerrillas to exist for long in the enemy's rear. Such a belief reveals lack of comprehension of the rela- 
so he sought to eliminate barriers between the cadres and peasants through a sublimation of class consciousness. Bula-Bula goes on to list Mulélés eight commandments, which, he explains in an unqualifiedly positive tone, created an alternative society in the maquis, one that was not based on capitalism, but "a new Congolese society based on the equality of people" (45).

Verhaegen renders this appropriation even more explicit by including Mulélé and Mao's codes of behavior next to each in his Rebellions au Congo, writing, "The correspondence between the text of Mao Tse-toung and that of the Muléliste doctrine is almost perfect" (122). I reproduce Verhaegen's comparison (122-3) here:

A) Eight Rules That Partisans Must Follow

1. Deal respectfully with all men, including evil-doers.

2. Buy things from villagers in full and don't steal.

3. Return borrowed things on time and without haggling.

4. Pay for what you have destroyed and do so willingly.

5. Don't hit or injure others.

6. Don't destroy or trample the fields of villagers.

7. Respect women and don't treat them as playthings.

8. Don't make suffer those you capture in battle (don't mistreat prisoners of war). Don't confiscate and don't take their personal items, for example, rings, money, watches, or anything else.
A) Eight Recommendations

1. Speak politely.

2. Pay in full what you buy.

3. Return everything you borrow.

4. Replace or give just monetary compensation for everything you damage.

5. Don't hit or injure others.

6. Don't damage the harvest.

7. Don't take liberties with women.

8. Don't mistreat prisoners.

tionship that should exist between the people and the troops. The former may be likened to water the latter to the fish who inhabit it. How may it be said that these two cannot exist together?" (Griffith 93) 
These rules were not always followed, as both Entre les eaux and Verhaegen's text suggest, although Abo Léonie and Théophile Bula-Bula's accounts are more sanguine in their descriptions of the maquis' overall comportment. Despite these differing accounts, what is clear is that Mulélé explicitly transposed the rules of the Chinese Revolution onto the Congolese struggle, adding instructive gloss and specifics deemed necessary to the Kwilu-based rebellion. If anything, Mulélés code is even stricter, especially with regard to the spirit (de bon coeur) with which a partisan should engage with villagers and even with the so-called villainous elements among them. Mulélé's list of commandments is also particularly attuned to issues of looting, either from captured prisoners or local populations, which, according to firsthand missionary and other reports, was largely not followed after the offensive launched in January $1964^{33}$ (Verhaegen Rebellions 124).

In Entre les eaux, Landu soon finds himself caught in the crosshairs of this strict, revolutionary code, especially in its practical contradictions. For example, during his first raiding mission, he must kill to demonstrate his loyalty, given his background as a Catholic priest. He also struggles with maintaining chastity while developing romantic feelings, both heterosexual and homosexual, for other comrades, including the Colonel himself; he thus conflates revolutionary ardor with romantic desire, which is a trope also found in literature written during the Chinese Revolution. ${ }^{34}$ In addition to these existential challenges concerning violence, his own sexuality, and the rigorous ideological and physical training he receives, the daily grind of everyday life in the bush begins to take its toll.

His interior monologue loudly and persistently debates whether or not to transgress the maquis' strict code of behavior, going even so far as to question the cuisine: "Beans and sweet potatoes. Not, Marx, not Lenin, not Mao requires us to eat so much of either. Why not detach a few riflemen and send them off hunting? We'd have game. The revolution would not be delayed" (Mudimbe Between 102). Landu correlates the monotony of cuisine with the perils of ideological purity. This correlation broaches the spatio-temporal deferral - namely, the revolutionary limbo he experiences as a maquisard committed to the "permanent revolution" of a protracted guerrilla war of attrition. He even connects this desire for better physical nourishment with his Christianity: "Nobody recommends beans and sweet potatoes out of love for the poor. Not Christ himself. He ate simply but not badly" (102). The passage captures how Landu can never tained at the hand of the Congolese/Zairian army, see Kalema 2018. 
fully prevent himself from finding the contradictions that inhere in every code of conduct, in every fundamentalism, whether political or religious. In short, he can never believe as a simple act of faith. The constant flux of his interior monologue belies the conviction with which he takes revolutionary action, foreshadowing the empty interiority of his eventual disillusionment by the novel's end.

Landu finally gives voice to his frustration by writing a letter to his Jesuit superior, a bookend to an initial letter he wrote explaining why he left the parish to join the rebellion. In this earlier letter, he describes the existential crisis that has precipitated this action: "I want to join others in creating a new world, where our Lord Jesus will no longer be disfigured. [...] To remain here in the parish would be to betray my conscience as an African and a priest" (24). This epistolatory device in fact reflects real events within Mulélés maquis. In his Rebellions au Congo, Verhaegen includes a letter the priest Placide Tara wrote to "a friend in Léopoldville" in April 1964, detailing the conditions of rebel camps and the charismatic leadership of Mulélé (162). As mentioned in the introduction, Landu conflates these two historical figures. He represents Tara through the actions of letter writing and ideological instruction ${ }^{35}$ (gleefully teaching from the French Jesuit Jean-Yves Calvez's The Thought of Karl Marx), ${ }^{36}$ and Lankwam through his imprisonment and death sentence for an alleged betrayal. ${ }^{37}$

In the second letter, this time to Jaak von Kroes, bishop of Makiadi, Landu reports that "the National Liberation Movement directing this revolution is by no means independent, whatever they claim. The general tone of the camp and the presence of Chinese arms would indicate that the NLM is an obedient communist front, inspired by Peking" (Mudimbe Between 87). By divulging this information on the nature of the maquis, Landu not only vents his frustration with the contradictions of orthodoxy - whether religious or political - but also puts into doubt the veracity of his interior monologue; it makes Landu an unreliable narrator. Up until this point, his equivocations do not necessarily render the reader skeptical of his politico-religious commitment. In fact, his constant

35 According to Abo Léonie, "The abbot Tara proves to be an excellent political and military instructor" [...] "Before independence," he says, "I had already read books on China [...] The Chinese Revolution is quite a bit like our war [...] It's a popular war, a war of the masses, since partisans, in order to be able to fight against the enemy, must be in perfect sympathy with the population" (Martens Une femme 143-4).

36 See the entry for "Calvez, Jean-Yves, sJ (1927-2010)" in The Cambridge Encyclopedia of the Jesuits (2017).

37 "It seems as though at least one abbot paid with his life for refusing to follow along with Mulélé" (Verhaegen Rebellions 96). In the footnote, "it is Abbot Adolphe Landwam, whose death was announced by several people" (96). 
mental struggle pinpoints an earnestness to make his spirituality concretely material.

Yet, the letter crystallizes Landu's experiences thus far in the maquis through a tone that slips into something reminiscent of espionage. He describes the maquis as the Congolese arm of global Maoism, not only capturing the centrality of the Chinese Revolution as inspiration for a radical Congolese postcolonialism but also furthering the motif of covert interventionism and Chinese soft power, which Bofane's Congo Inc. and Mujila's Tram 83 explore in the contemporary context. ${ }^{38}$ Bidoule, who was never fully convinced of Landu's conversion, intercepts this letter and, in the Colonel's absence, imprisons Landu as a traitor. But before the death sentence can be carried out by a shooting squad, government troops invade the camp, killing many rebels and scattering the rest. Landu and a fellow comrade, Antoinette, escape into the bush, marking the end of the priest's career as a maquisard and catalyzing his disillusionment with all belief, a "debauchery of empty symbols," with which his interior monologue, now void of conviction, concludes (Mudimbe Between 150).

Before I turn to the contemporary context, I would like to signal another way that Mao served as a symbol in the Congo. Although Mudimbe's Entre les eaux incorporates a Maoism through the figure of the anti(neo)colonial guerrilla, another figure that emerges during the Cold War is the "dear leader," embodied by the turn to authoritarianism in many African states following the disillusionment with the possibilities of independence. With the defeat of the Mulélélistes in 1968, Mobutu quickly moved to appropriate Lumumba's revolutionary legacy, and consequently that of Mulélés Maoism.

One way in which Mobutu appropriated this revolutionary legacy was through the Manifeste de N'sele (1967), widely reputed to have been written by Mulélé. This document has murky origins. Mobutu claims the text was written during one of his trips to N'sele, a suburb along a river outside of Kinshasa where he kept an abode. However, according to Abo Léonie, during one of the campaigns earlier that year, Mulélé and one of his deputies spent long days drafting a manuscript that would help unite the Eastern and Western fronts of the rebellion - what she says he called a "Popular Movement of the Revolu-

38 Landu's vacillations over the ideology of the maquis could also reflect the actual historical debate over the Simba Rebellion's affiliation with global Maoism. See Monaville 2018. 
tion" (Martens Une femme 203). During a skirmish with Mobutu's troops soon afterwards, the document went missing, much to the chagrin of Mulélé, who immediately set to work attempting to reconstruct the document from memory. Mobutu soon published the Manifeste de N'sele, which featured, as Isidore Ndaywel è Nziem writes in his Histoire Générale du Congo, the curious appearance of the same formulation, a "Popular Movement of the Revolution" (Ndaywel 668). Ndaywel, along with Abo Léonie, asserts that this formulation represents how Mobutu attempted to fill the political void of the Kinshasa-based government, appropriating a revolutionary populism by plagiarizing Mulélé. ${ }^{39}$

Another way in which Mobutu appropriated this legacy was through the figure of Mao himself, capturing the paradox of how Maoism circulated as a symbol following the advent of China's Cultural Revolution. ${ }^{40}$ This paradox resides in how Maoism was both ideological inspiration for Mulélé's Rebellion and how Mobutu manipulated the signs and symbols of state power. The controversial legacy of Maoism in the Congo means the Chinese Revolution simultaneously symbolized both anti-imperialism and authoritarian rule. In fact, this contradiction is precisely what many African states faced when the leaders of anticolonialism, often leftist-leaning and supported by the Soviet Union or Maoist China, came to power against the backdrop of Cold War realpolitik; it is the pitfall of national consciousness that Frantz Fanon famously describes in The Wretched of the Earth (1961), wherein the national bourgeoisie manipulates both a nativist nationalism and a revolutionary politics to inaugurate a neocolonialism.

Mobutu's legacy lies squarely in this vein. Due to the scope of this article, I will not repeat the extensive scholarship that deals with Mobutu's complicity with the CIA, Zaïrianisation, Mobutism, and general dictatorial rule from 1965 to his death from prostate cancer in $1997 .{ }^{41}$ However, two symbolic appropriations of Maoism are pertinent to facilitate my argument's transition from the 1960s Third Worldism of revolutionary Congo and to the contemporary context. Both of these examples illustrate the ways in which Mobutu styled his own personality cult after that of Mao Zedong.

39 Mulélé is alleged to have said that "in the outskirts of Eyens, I wrote, for the maquis, documents to create a popular revolutionary movement. The soldiers took it up. And now, Mobutu, who always fought against the revolution and against the people, and who will continue to do so, copies our ideas and our watchwords to confuse us" (Martens Une femme 221).

40 See Yoon 2015. The phrase "symbolic Maoism" comes from Fredric Jameson's article, "Periodizing the 6 os" (1984).

41 See Weissman 2014; White 2006; and Verhaegen and Vale 1993. 


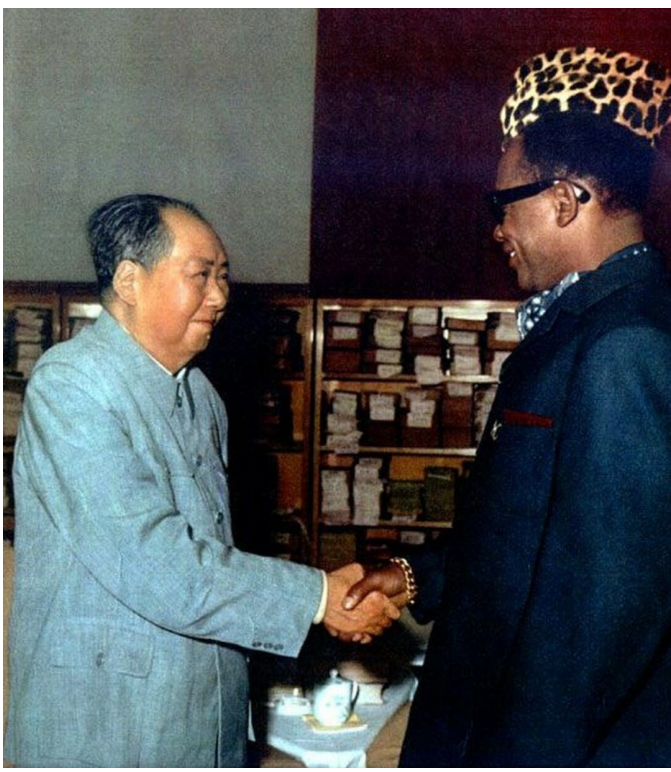

FIGURE 1

Mobutu and Mao

HTTPS://WWW.PINTEREST.COM/PIN/6975654297578

O2415/. 6 MAR. 2020.

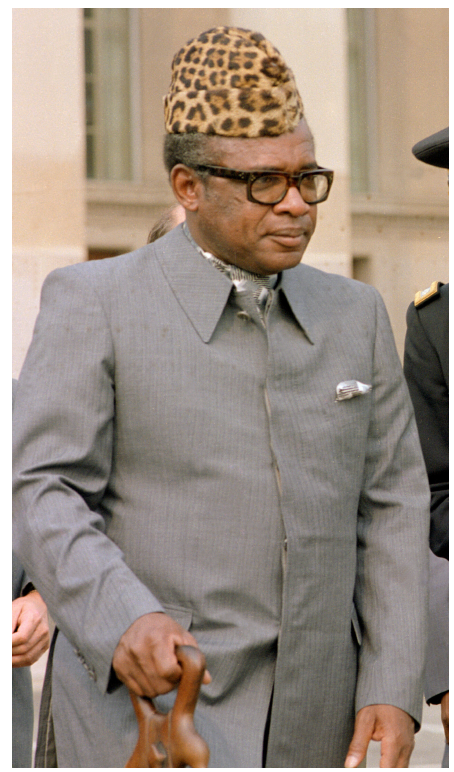

FIGURE 2

Mobutu Sese Seko

WIKIPEDIA, 6 MAR. 2O2O, HTTPS://EN.WIKIPEDIA.ORG/ W/INDEX.PHP?TITLE $=$ MOBUTU _SESE_SEKO\&OLDID $=944247226$

1 JUNE. 2021

Mobutu's characteristic abacost (à bas le costume) was an homage to the Chinese leader and the tunic he popularized, widely known as the Mao suit (see Figures 1 and 2). Mulélé himself was also known to wear the le col Mao (see Figure 3).

Within the Chinese context, the suit was first popularized during the 1920 s under San Yat-sen. The "Sun Yat-sen suit (or Zhongshan zhuang) had a high turn-down military-style collar and four symmetrically placed gusseted patch pockets" (Langkjaer 228; see Figure 4). The suit blends Chinese traditional dress with military uniform to differentiate an alternative sartorial modernism from the Western-style business suit. Mao continued to proletarianize the fashion during the Cultural Revolution to the point that "the Chinese were seen as a human sea of blue-uniformed revolutionaries," or more pejoratively as "blue ants" (Langkjaer 228). If Mao proletarianized the Sun Yat-sen suit, demonstrating "that in plainness lay power," Mobutu rendered it Congolese through the use of local textile patterns and by adding his signature leopard skin hat and ascot (Langkjaer 228) (see Figure 5). Just as Mobutu allegedly stole Mulélé's papers to 


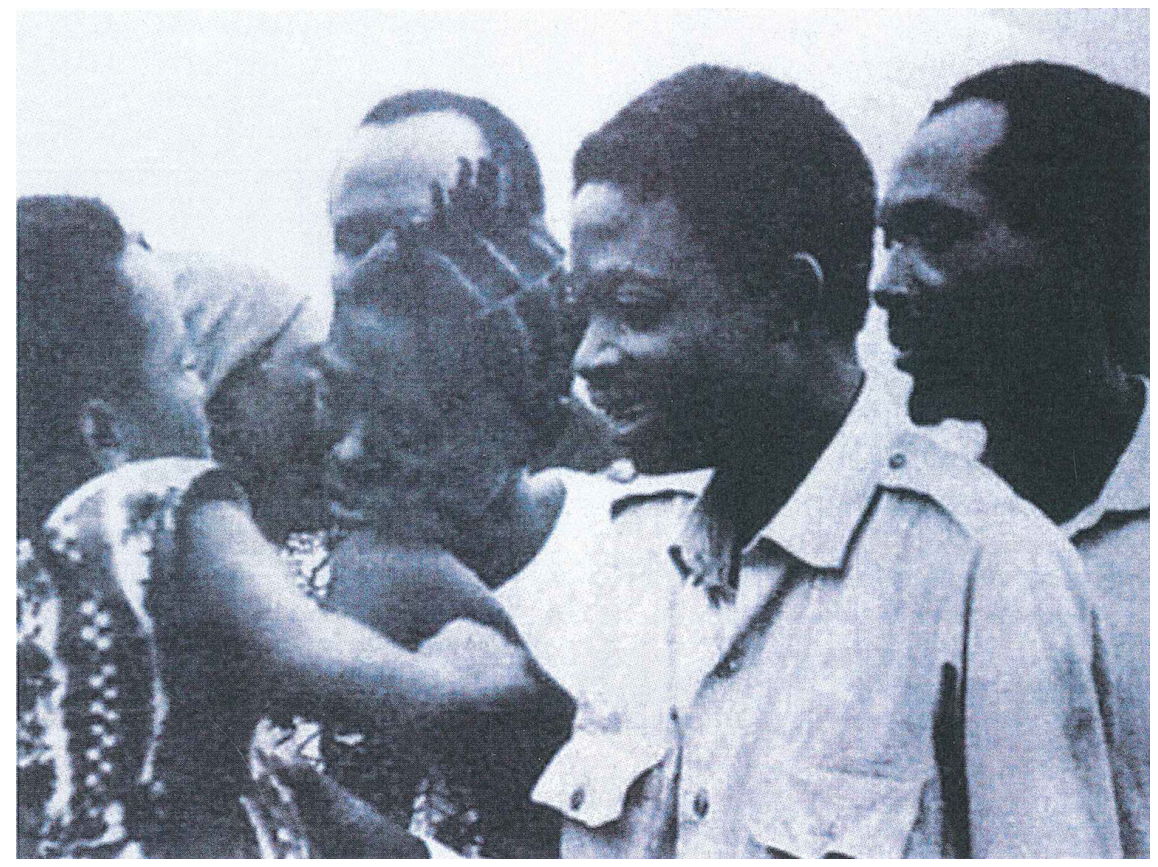

FIGURE 3 Pierre Mulélé

HTTP://WWW.MBOKAMOSIKA.COM/ARTICLE-1968-L-ASSASSINAT-DE-PIERRE -MULELE-11517682O.HTML. 6 MAR. 2020

conceive of the "Popular Movement of the Revolution" in Manifeste de la N'sele, Mobutu's fashion choices instrumentalize both Chinese revolutions (nationalist and communist), as well as visually sever Mulélé's claim to Lumumba's legacy and Third World radicalism.

The Manifeste was not the only document through which Mobutu sought to appropriate the accouterments of revolutionary politics. Although sometimes confused with the Manifeste due to its similar small, handbook-like appearance, Mobutu's Paroles de président (Words of the President) (1968) was in fact an attempt to shore up his personality cult styled after Mao by publishing a Little Green Book as opposed to a Little Red Book (see Figures 6 and 7). The presentation of the Little Green Book is an explicit attempt to create the kind of iconography that Mao's picture accomplished in its almost ubiquitous circulation within revolutionary circuits both within and without the West. As the postscript to the book states, "This Little Green Book [...] uses excerpts of the speeches and pronouncements of the Lieutenant-General Joseph Désiré Mobutu, President of the Democratic Republic of the Congo from July 196o to March 1970" (Mobutu 94). ${ }^{42}$ The book includes quips like, "What man could 


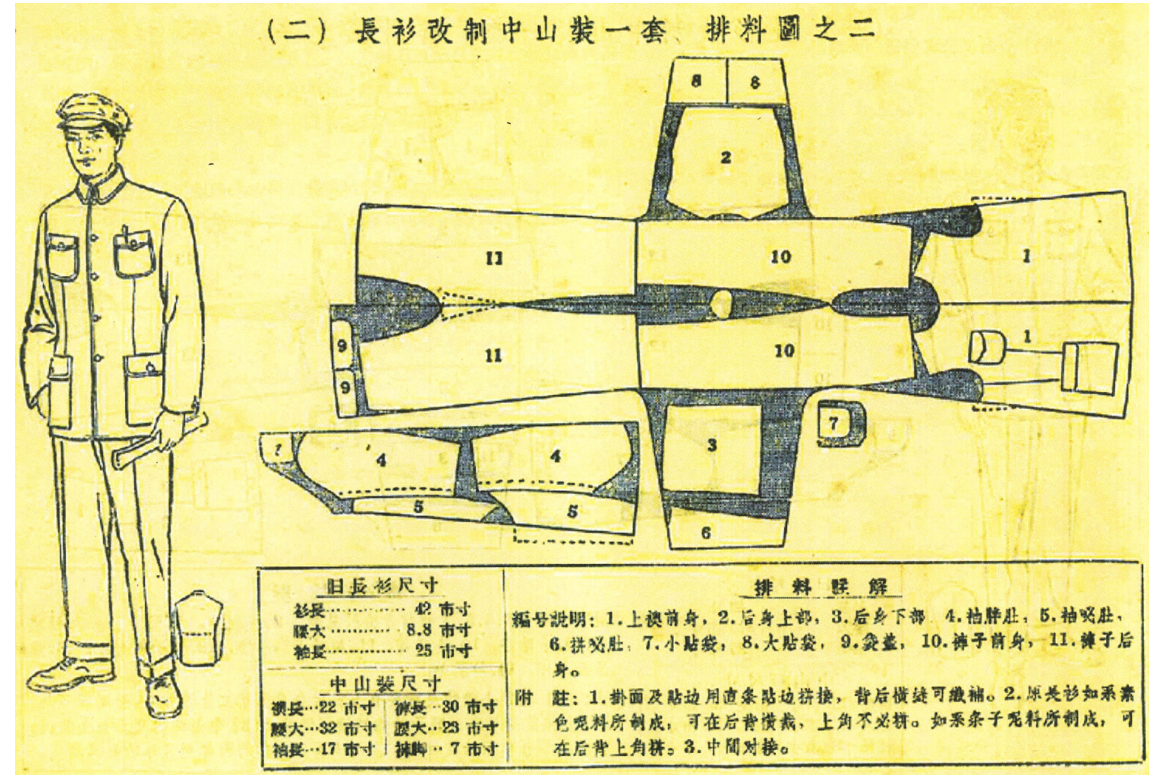

$-8-$

FIGURE 4 The design of the Mao Tunic REPRODUCED IN LANGKJAER 228

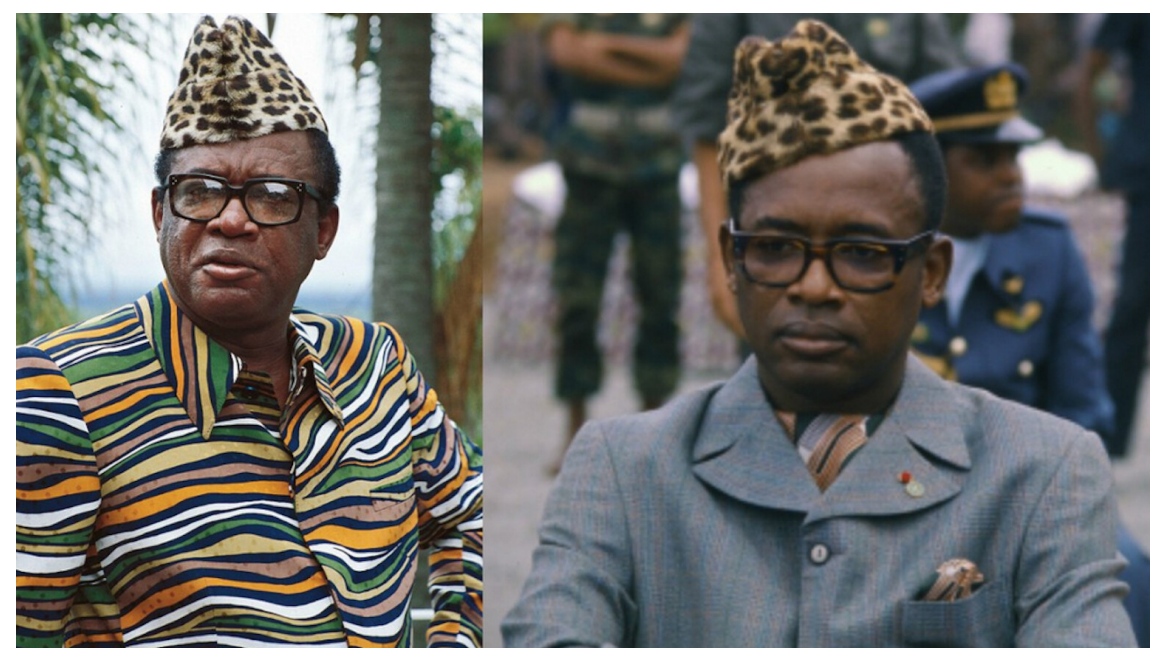

FIGURE 5 Mobutu's Abacost

HTTPS://THEODOREDALRYMPLE.WORD

PRESS.COM/CATEGORY/ABACOST/. 6 MAR. 2020 


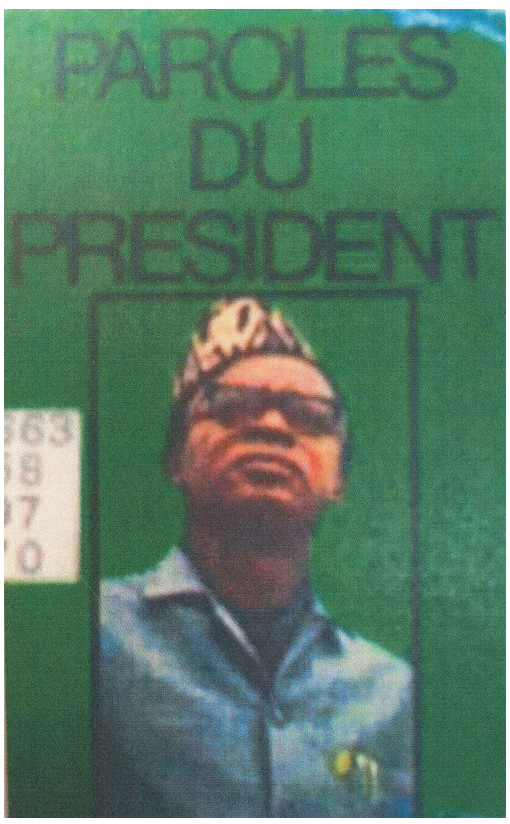

FIGURE 6

Mobutu's Little Green Book

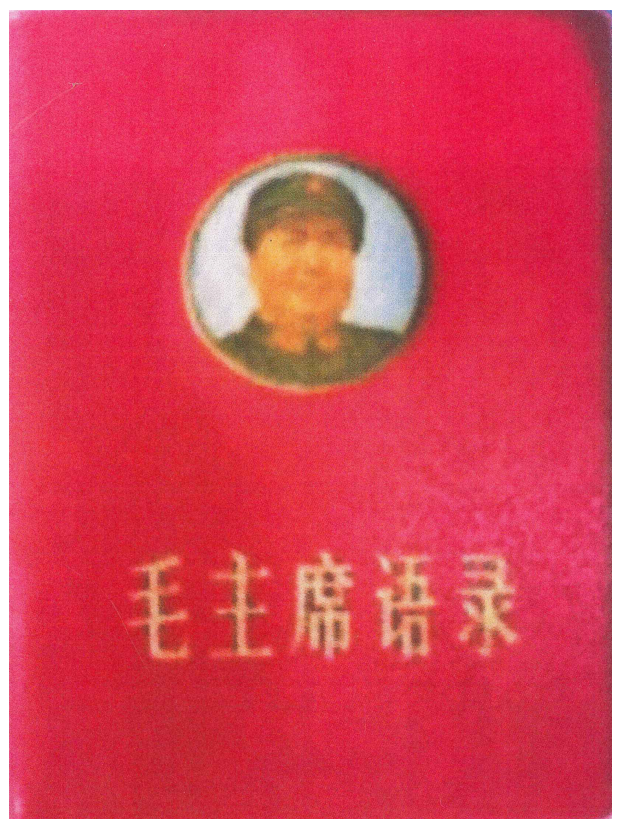

FIGURE 7

Mao's Little Red Book

HTTP://VEEKAYBEE.GITHUB.IO/WLB/2012/10/10 -BOOKS-EVERY-MBA-STUDENT-SHOULD-READ/.

6 MAR. 2020

destroy his canoe in the middle of the river?" as well as declarations of militancy, such as, "The wealthy and the powerful must realize that Mobutu is before all else a soldier and that he isn't scared of war or of death" (7). The text also attempts to differentiate Kinshasa from Moscow and Beijing by paving a middle road between capitalism and communism.

In sum, Mobutu cloaked his dictatorship with Third Worldist rhetoric, laying claim to the revolutionary legacy of Lumumba by appropriating Mulélé's Chinese-inspired populism. He then fortified his political power by promoting a Maoist-like personality cult through the requisite iconography and dogma, as well as by implementing social policies such as authenticité (authenticity) and Zaïranisation (Zairanization), his own version of the Chinese Cultural Revolution. ${ }^{43}$ A classic reactionary in Marxist terms, Mobutu represents the neoco-

43 "Since authenticity was perceived as a cultural revolution, just like the father of the Chinese cultural revolution Mao Tse Tsoung, Mobutu pushed the analogy all the way to publishing the little green book (quotes of President Mobutu), an allusion to the little red 
lonial transition from the period of anticolonial struggle and how contemporary DRC-PRC relations draw upon this history of Afro-Asian solidarity to justify a new era of extractivism as a celebratory "win-win" for development and mutual exchange, the literary imaginaries of which I will now examine.

\section{The Extractivists and Economic Tourists}

By the end of the first quarter of the twenty-first century, the PRC's presence in the Congo is emphatically no longer a revolutionary force, but an economic one. The rhetoric of Afro-Asian solidarity has morphed into the slogan of a "win-win" for development, which accompanies virtually every joint venture between the PRC and African countries. In this last section, I consider how Mulélés Maoist legacy as the figure of the guerrilla fighter, or maquisard, manifests in the new figure of the mondialiste in In Koli Jean Bofane's Congo Inc.: Bismarck's Last Testament (2014). I then conclude by analyzing the Chinese "economic tourist" in Fiston Mwanza Mujila's Tram 83 (2014). These texts demonstrate how new patterns of globalization have further transformed these revolutionary and authoritarian tropes into figures of extraction, or what I call the extractivist.

Congo Inc. received both the Grand Prix du Roman Métis in 2014 and Le Prix des Cinq Continents de la Francophonie in 2015. The novel depicts, among other dynamics, how a stranded Chinese national, Zhang Xia, collaborates with a half-pygmy, Isookanga, from the Salonga Province on the streets of Kinshasa to sell bags of water they call eau pire suisse, or "Pure/Worse Swiss Water."44 This hustling mentality pulls from how Chinese investment in the Congo has transformed the patterns of globalization and informs, in particular, Isookanga's postcolonial consciousness. He desires to be a mondialiste - namely, an agent of globalization that has little to no qualms in exploiting his province's natural resources in order to track his way into the global economy before climate change stagnates even the possibility of a developmental modernity.

I have discussed the way in which the novel, and specifically the term mondialiste, imagines a new spatio-temporality of the Global South for the Congolese postcolony elsewhere. ${ }^{45}$ What I would like to focus on here is the way in which

book (quotes of President Mao Tse Tsoung)" (Ndaywel 684). I thank Matthew Reeck for his translation of the Ndaywel text.

44 They mispronounce the word "pure" in French as "pire" or "worse," rendering the sales pitch ironic.

45 See Yoon 2020. 
the revolutionary legacy of Muléle and the Simba Rebellion manifests in the text during a critical scene wherein Zhang Xia and Isookanga have teamed up with a band of street children, or "shégués," to take a few municipal officers hostage after one of their band was brutally shot down in the street. ${ }^{46}$ In the ensuing standoff with the municipal governor, the children turn to Isookanga for help, as they consider him the adult of the group. Equally perplexed by the situation, Isookanga asks, "Zhang Xia, you come from a country that has achieved its revolution; what's your advice?" (Bofane 65).

A product of the revolution's dogmatic legacy, Zhang Xia immediately begins quoting a 1964 speech by Mao in support of the Mulélé Rebellion, "Shégué people, let us unite to bring down the American aggressors and their lackeys! Let the shégués listen only to their courage, let them dare do battle, let them brave trouble, and the whole world will be theirs. The brutes will all be annihilated" (65). In a propaganda publication by Beijing Foreign Language Press, In Support of the People of the Congo (Leopoldville) Against U.S. Aggression (1965), the part of Mao's speech that Zhang Xia quotes is rendered as: "People of the whole world, unite and defeat the U.S. aggressors and all their running dogs! People all over the world, be courageous, dare to fight, defy difficulties and advance wave upon wave. Then the whole world will belong to the people. Monsters of all kinds shall be destroyed" (Mao 3). Putting aside the different resonances due to issues of translation, this instance of intertextuality infuses the shégués' revolt with the revolutionary cachet of Mulélés Maoism. The passage suggests Mulélés radical Third Worldism is somehow still relevant to the contemporary moment wherein Chinese investment in Congolese infrastructure has taken center stage. A new lumpenproletariat has formed, comprised not only of a lost generation of Congolese youth but also of any marginalized figure of globalization, ranging from exploited Chinese and Congolese laborers to displaced villagers and even, in a planetary sense, the flora, fauna, and minerals now extracted at an unprecedented scale.

Delighted by how this now defamiliarized revolutionary rhetoric has stirred the shégues to a fevered pitch, Isookanga puts an ironic spin on this updated Mulélé Rebellion, telling Zhang Xia, "You and I are going to globalize the revolution, friend" (Bofane 67). Combined with the moral ambiguity of Isookanga's mondialisme, the reader is left wondering which revolution Isookanga means a Maoist or extractivist one - and whether or not he even distinguishes between the two. At this moment, Isookanga embodies the paradox that is the transition

46 Strikingly, some scholars have pointed to how the moniker, shégue, may in fact be derived from the name of Che Guevara, yet another icon in the pantheon of global Marxism. See Geenen 2009. 
of the Chinese state from a locus of radical Third Worldism to the world's factory, and now as foreign direct investor in the Congolese economy. The passage evinces the contradiction of how the revolution is still "made in China," only now defamiliarized according to the PRC's desire to move up the global value chain.

Mujila's Tram 83 also captures these new flows of globalization albeit in a desultory, stream-of-consciousness style. The novel distinguishes between non- and for-profit tourists, the latter of which includes the Chinese. If Pierre Landu's interior monologue becomes increasingly convoluted as he strives for dogmatic clarity, the narrator in Tram 83 embraces the discontinuity and contradictions of Isookanga's mondialiste consciousness. Three main characters Lucien, Requiem, and Malingeau - have provoked the ire of the governor by publishing naked pictures of him as well as depicting his death in a stage play. They each find a way to obtain "asylum in the official residence of the Chinese tourists" (Mujila 209). While Congo Inc. explores how the legacy of Maoism and the Mulélé Rebellion manifests in contemporary extractivism, Tram 83 demonstrates how any rhetoric of solidarity is in fact meant to shore up the tenuous stability of the "win-win" status quo. The narrative captures how the figure of the economic tourist is void of any ideological conviction, choosing instead to act according to what will help maintain processes of extraction in the short term.

The narrator describes the Chinese as one type of tourist among many "[i]ndividuals banded together according to geographical state" (88). These include "the for-profit tourists, the colored tourists, most of whom were poor, the white tourists, and finally, the Chinese, who refused to mix with the others and always moved around in a tight bunch, even in the mixed facilities" (88). The Chinese are depicted as both hermetic and moving according to their own touristic temporality, a practice of self-segregation that has fed false rumors that the PRC is using prison labor on the continent. ${ }^{47}$ The narrator turns an anthropological gaze onto these profit-seeking foreigners, describing how "these castes displayed their own internal subdivision, often hinging upon money and fairness of skin" (88). The economic tourists perpetuate hierarchies of difference based on colonial categories of race combined with monetary worth. This economic tourism thereby adds a temporary texture to postcolonial extractivism, wherein there seems to exist no durable model of investment. The exhaustion of natural resources is now a real possibility, the first time such

47 For a discussion of myths versus realities, see the conclusion of Deborah Brautigam's The Dragon's Gift: The Real Story of China in Africa (2011). 
material finitude has been placed on development through industrialization. This approach recalls how the mondialiste focuses overwhelmingly on taking advantage of whatever opportunity arises because future opportunities are not guaranteed. Thus these economic tourists have come to visit and take resources as souvenirs, returning home to describe the literally "enriching" experience of the Congo.

While the narrator describes the Chinese tourists as emphatically for profit, they are not entirely of the same ilk. Not only are they powerful enough to provide asylum for the three provocateurs but they also enjoy "combining business with pleasure" by "order[ing] rounds for the whole of Tram 83 " after the "national team had won the [football] game [against Cameroon]" (202). They then also urge, "We can give you something to eat if it's hunger that's made you lose your head" (202). The Chinese tourists are ready and willing to grease future transactions, which the passage hints might include bribery and corruption. These kinds of gifts are reflected on a grander scale in the form of prestige projects such as stadiums, hospitals, and municipal buildings constructed in order to curry favor with incumbent administrations. However, this generosity is not altruistic because when the bounty on Lucien, Requiem, and Malingeau increases, it causes "the attitude of the Chinese tourists to change. They were no longer kind and obliging vis-à-vis the three fugitives" (209). The narrator captures the swiftness with which the Chinese turn to an "economic pragmatism," underlining the precarity of this "temporarality" (Shinn and Eisenman 6; Mujila 209).

The Chinese tourists explain "our business is floundering, but if we could truly gain the favor of the dissident General [...] [He] is now offering seventy thousand dollars, while we only need twenty thousand dollars to save our firm from bankruptcy" (Mujila 209). The passage reveals that these economic tourists are in fact dependent upon the corrupt elites of this quasi-militarized city-state to maintain their business. This Congolese agency, however fraught, is often ignored due to both the sordid history of authoritarian rule, nepotism, and the overwhelming focus on the PRC creating new states of dependency on the continent. As a result, both an existential and material precarity dominates the Congolese city-state as postcolony, demonstrating the paradox of Africa-China globalization as both utterly transformative and exceedingly tenuous. 
As this essay has demonstrated, Congolese literature has long invoked China as a trope, reaching as far back as the years of independence and the ensuing Congo Crisis. Mudimbe's Entre les eaux demonstrates how Mulélés Rebellion incorporated Maoism into the guerrilla war, juxtaposing a revolutionary politics against the Cold War and an inchoate postcolonialism. This atmosphere intertwined radical Marxism, Christianity, and pan-Africanism through the characters of the guerrilla fighter and radical intellectual in an attempt to locate the optimal path to decolonization and national self-determination. Yet under Mobutu, Maoism no longer symbolized a politics of opposition based on mobilizing the peasantry, but rather authoritarian power through a personality cult and state propaganda, as exemplified by Mobutu's abacost and publication of the Little Green Book. During the Cold War, Maoism thereby manifested as a paradox in the Congo, simultaneously inspiring both rebels and dictator.

The end of Mobutu's dictatorship saw the rise of Chinese foreign direct investment in the DRC during the first twenty years of the twenty-first century. China as a trope in Congolese literature reflected this change. Bofane's Congo Inc. recasts Mulélé's Maoism to address the disenfranchisement brought about by a new era of globalization wherein the PRC attempts to move up the global value chain by implementing an economics of extraction in the Congo. New figures emerge, such as the mondialiste and, in Mujila's Tram 83, the economic tourist. These figures lend a moral ambiguity to current collaborations and the accompanying "win-win" rhetoric. An urgency to exploit, to become an agent of globalization rather than passive recipient, now characterizes a Congolese postcolonialism that must respond to a new era of development precarity and requisite social dislocations, albeit of a substantially different variety than those of the Cold War era.

In conclusion, the jury remains out as to whether DRC-PRC relations will prove developmentally beneficial for the DRC in the long term or whether their relations will only perpetuate a politico-economics of extraction. Yet one thing remains certain: Congolese writers will continue to interrogate these dynamics, figuring Africa-China relations and, in the best tradition of postcolonialism, catalyzing critique through literary imaginaries.

\section{Works Cited}

"Africans Also Investing in China." Africa Renewal. 19 Jun. 2015. Web. 14 Apr. 2021. Alden, Chris. China in Africa. London: Zed Books, 2010. 
Alden, Chris, Daniel Large, and Ricardo Soares de Oliveira. China Returns to Africa: A Rising Power and a Continent Embrace. Oxford: Oxford UP, 2008.

Banham, Martin, James Morel Gibbs, and Femi Osofisan. China, India and the Eastern World. Woodbridge: James Currey, 2016.

Batchelor, Kathryn, and Xiaoling Zhang. China-Africa Relations: Building Images Through Cultural Co-operation, Media Representation, and Communication. Oxfordshire: Routledge, 2017.

Bofane, In Koli Jean. Congo Inc.: Bismarck's Testament. Trans. Marjolijn de Jager. Bloomington: Indiana UP, 2018.

Brautigam, Deborah. The Dragon's Gift: The Real Story of China in Africa. New York: Oxford UP, 2011.

Brautigam, Deborah. Will Africa Feed China? Oxford: Oxford UP, 2015.

Bula-Bula, Théophile. Pierre Mulele et le maquis du Kwilu en RD Congo témoignage d'un survivant du maquis. Paris: L'Harmattan, 2010.

“China Global Investment Tracker." American Enterprise Institute - AEI. Web. 4 Oct. 2019.

Césaire, Aimé, and Robin D.G. Kelley. Discourse on Colonialism. New York: Monthly Review Press, 2000.

Communist International Congress. Second Congress of the Communist International: Minutes of the Proceedings. London: New Park Publications, 1977.

"Data: China-Africa Trade." China Africa Research Initiative. Web. 4 Oct. 2019.

Diagne, Souleymane Bachir. African Art as Philosophy: Senghor, Bergson and the Idea of Negritude. Kolkata: Seagull Books, 2011.

Diagne, Souleymane Bachir. Postcolonial Bergson. New York: Fordham UP, 2019.

Diawara, Manthia. "Reading Africa Through Foucault: V.Y. Mudimbe's Reaffirmation of the Subject." October 55 (1990), 79-92.

Dongala, Emmanuel Boundzéki. Un fusil dans la main, un poème dans la poche: roman. Paris: Serpent à plumes, 2003.

Fanon, Frantz, and Richard Philcox. The Wretched of the Earth: Frantz Fanon; Translated from the French by Richard Philcox; Introductions by Jean-Paul Sartre and Homi K. Bhabha. New York: Grove Press, 2004.

Gasana, Ndoba. "Entretien avec Vumbi Yoka Mudimbe." Presence Africaine 146:2 (1988), 219-35.

Geenen, Kristien. “'Sleep Occupies No Space': The Use of Public Space by Street Gangs in Kinshasa." Africa:Journal of the International African Institute 79:3 (2009), 347-68.

Glissant, Édouard. Poetics of Relation. Ann Arbor: University of Michigan Press, 1997.

Gott, Richard. "Che Guevera and the Congo." NLR I/22O, November-December 1996. New Left Review. Web. 5 Mar. 2020.

Griffith, Samuel B., and Zedong Mao. Mao Tse-Tung on Guerrilla Warfare. New York: Frederick A. Praeger, 1961. 
Jameson, Fredric. "Periodizing the 6os." Social Text 9/10 (1984), 178-209.

Kalema, Emery M. “Scars, Marked Bodies, and Suffering: The Mulule 'Rebellion' in Postcolonial Congo." The Journal of African History 59:2 (2018), 263-82.

Kapanga, Kasongo M. "L' CEuvre Romanesque de Mudimbe et Le Discours Identitaire Zaïro-Congolais." French Forum 31:1 (2006), 55-74.

Kasende, Luhaka. "L'ironie comme modalité de réévaluation des discours hégémoniques Dans Entre les eaux de V.Y. Mudimbe." Études littéraires 33:1 (2001), 169-85.

Kikumbi, Annette Lembagusala, and Marc Depaepe. "L'Éducation Des Filles Congolaises Au Maquis de Mulele: Arme de Libération Ou Force d'(Auto)Destruction?" Historical Studies in Education / Revue d'histoire de l'éducation 30:1 (2018), Web.

Kisukidi, Nadia Yala. "Du christianisme comme 'expérience de conflit.” Une lecture d'Entre les eaux de V.Y. Mudimbe." ThéoRèmes. Penser le religieux 4 (2013), Web.

Langkjaer, Michael A. "From Cool to Un-Cool to Re-Cool: Nehru and Mao Tunics in the Sixties and Post-Sixties West.” In Global Textile Encounters. Eds. Marie-Louise Nosch, Zhao Feng and Lotika Varadarajan. Philadelphia: Oxbow Books, 2014, 227-35.

Linares, Immaculada. Littératures francophones. Valencia: Universitat de València, 1996. Liu, Jianmei. Revolution Plus Love: Literary History, Women's Bodies, and Thematic Repetition in Twentieth-Century Chinese Fiction. Honolulu: University of Hawai'i Press, 2003 .

Lüthi, Lorenz M. The Sino-Soviet Split: Cold War in the Communist World. Princeton: Princeton UP, 2010.

Mahler, Anne Garland. From the Tricontinental to the Global South: Race, Radicalism, and Transnational Solidarity. Durham: Duke UP, 2018.

Mao, Zedong, et al. The Secret Speeches of Chairman Mao: From the Hundred Flowers to the Great Leap Forward. Trans. Timothy Cheek. Cambridge: Council on East Asian Studies/Harvard University, 1989.

Martens, Ludo. Pierre Mulele, ou, La seconde vie de Patrice Lumumba. Berchem (Anvers), Belgique; Bruxelles: EPO; Distribution Editions Vie ouvrière, 1985.

Martens, Ludo. Une femme du Congo. Bruxelles: E PO, 1991.

Mobutu Sese Seko. Paroles du Président. Kinshasa: Editions Zaïre, 1970.

Monaville, Pedro. "Making a 'Second Vietnam': The Congolese Revolution and Its Global Connections in the 196os." In The Routledge Handbook of the Global Sixties: Between Protest and Nation-Building. Eds. Chen Jian, Martin Klimke, Masha Kirasirova, Mary Nolan, Marilyn Young and Joanna Waley-Cohen. New York: Routledge, 2018, 106-18.

Monson, Jamie. Africa's Freedom Railway: How a Chinese Development Project Changed Lives and Livelihoods in Tanzania. Bloomington: Indiana UP, 2009.

Monson, Jamie. "Chapter 1 Futures in the Past of Africa-China Engagement." In Afrasian Transformations: Transregional Perspectives on Development Cooperation, Social Mobility, and Cultural Change. Eds. Ruth Achenbach, Jan Beek, John Njenga Karugia, Rirhandu Mageza-Barthel, and Frank Schulze-Engler. Leiden: Brill, 2O2O, 21-43. 
Mudimbe, V.Y. Between Tides. Trans. Stephen Becker. New York: Simon \& Schuster, 1991. Mujila, Fiston Mwanza. Tram 83. Trans. Roland Glasser. Special Etisalat edition, Dallas, Texas: Deep Vellum Publishing, 2016.

Ndaywel è Nziem, Isidore. Histoire générale du Congo: de l'héritage ancien à la répulique démocratique. Bruxelles: De Boeck \& Larcier, 1998.

Reiser, William. "Calvez, Jean-Yves, sJ (1927-2010)." The Cambridge Encyclopedia of The Jesuits. Ed. Thomas Worcester, SJ. Cambridge: Cambridge UP, 2017. 127-8.

Shih, Shu-mei. Visuality and Identity: Sinophone Articulations across the Pacific. Berkeley: University of California Press, 2007.

Shinn, David Hamilton, and Joshua Eisenman. China and Africa: A Century of Engagement. 1st ed. Philadelphia: University of Pennsylvania Press, 2012.

Slaymaker, William. "Agents and Actors in African Antifoundational Aesthetics: Theory and Narrative in Appiah and Mudimbe." Research in African Literatures 27:1 (1996), 119-28.

Strong, Tracy B., and Helene Keyssar. "Anna Louise Strong: Three Interviews with Chairman Mao Zedong." The China Quarterly 103 (1985), 489-509.

Swedberg, Richard. "The Idea of 'Europe' and the Origin of the European Union - A Sociological Approach." Zeitschrift für Soziologie 23:5 (2016), 378-87.

Taylor, Ian. China and Africa: Engagement and Compromise. New York: Routledge, 2007.

Taylor, Ian. China's New Role in Africa. Boulder: Lynne Rienner Publishers, 2009.

Thornber, Karen Laura. "Breaking Discipline, Integrating Literature: Africa-China Relationships Reconsidered." Comparative Literature Studies 53:4 (2016), 694-721.

van Waijenburg, Marlous. "Financing the African Colonial State: The Revenue Imperative and Forced Labor." The Journal of Economic History 78:1 (2018), 40-80.

Vasser, Uchenna P. “A Literary Approach to Afro-Sino Relations: Ufrieda Ho's Paper Sons and Daughters: Growing Up Chinese in South Africa and Ken N. Kamoche's Black Ghosts." Third World Quarterly 40:5 (2019), 999-1013.

Verhaegen, Benoît. Rebellions au Congo. Bruxelles: Centre de Recherche et d'Information Socio-Politique, 1966.

Verhaegen, Benoit, and Michel Vale. "The Temptation of Predatory Capitalism: Zaire Under Mobutuism." International Journal of Political Economy 23:1 (1993), 109-25.

Weissman, Stephen R. "What Really Happened in Congo: The CIA, the Murder of Lumumba, and the Rise of Mobutu The Cold War's Cold Cases." Foreign Affairs 93:4 (2014), 14-25.

West-Pavlov, Russell. "Participatory Cultures and Biopolitics in the Global South in In Koli Jean Bofane's Congo Inc." Research in African Literatures 48:4 (2017), 105-21.

White, Bob. "L'incroyable machine d'authenticité: l'animation politique et l'usage public de la culture dans le Zaïre de Mobutu." Anthropologie et Sociétés 30:2 (2006), $43-63$. 
Yoon, Duncan M. “Africa, China, and the Global South Novel: In Koli Jean Bofane's Congo Inc." Comparative Literature 72:3 (2020): 316-39.

Yoon, Duncan M. “'Our Forces Have Redoubled': World Literature, Postcolonialism, and the Afro-Asian Writers' Bureau." Cambridge Journal of Postcolonial Literary Inquiry 2:2 (2015), 233-52.

Young, Robert. Postcolonialism: An Historical Introduction. Chichester: John Wiley \& Sons, Inc, 2016. 